\title{
Without the Mon Paradigm
}

IMAGINe, FOR A MOMENT, early Burma and Mainland Southeast Asian history without the Mon Paradigm. What would it look like? There would be no Sona and Uttara bringing the most orthodox version of the Tipitakas to Lower Burma, no ancient Rāmaññadesa or Thatôn there, no conquest by Aniruddha in 1057, and no Mon Lower Burma civilizing of Burman Upper Burma. Can Burma scholars live with the idea of a Burmese civilization that began without Mon Theravāda Buddhist influence and a "Mon" period in Pagán? Indeed, can we envision just the opposite, a history in which Lower Burma Mon culture was actually the much later beneficiary of Pagán civilization, including its script, its art and architecture, its physical infrastructure, its Buddhism and conceptual system? Can Southeast Asianists also reject the assumptions undergirding the Mon Paradigm that ethnic conflict was the overriding framework of analysis, organization, and periodization of Burma's history? Can we come to terms with a different view of the history of Dvāravatī and Theravāda Buddhism in the region that suddenly materializes when the Mon Paradigm is removed? Can scholars of Southeast Asia even consider the origins of the state in Burma and parts of Mainland Southeast Asia without maritime trade and commerce as its primary cause, as implied by the Mon Paradigm?

If the answer is yes, then a major paradigm shift in Burma Studies is required. Much will have to be qualified, reinterpreted, or discarded. If the answer is no, then evidence, not mere analysis or assertion, must be provided to show not only that an ancient Rāmañnadesa did exist in Lower Burma before the late thirteenth century, but that all the consequences attributed to it and its alleged conquest are equally viable. Given the preponderance of the evidence, the choice is clear.

Removal of the Mon Paradigm would free scholarship from the straitjacket confining our current "knowledge" about early Burma, and its consequent impact on understanding the larger region. It would eliminate the 
burden of having to account for the alleged presence and significance of a very early Theravāda Buddhist Mon state and culture in Lower Burma every time new data is found there. This would affect the study of Burma and early Mainland Southeast Asia in very specific ways, the focus of this concluding chapter. However, since the story is part of a much longer chronology and a much larger geopolitical, cultural, and economic context than just the history of the Mon speakers in Lower Burma, the analysis is also placed in a much longer and larger conceptual framework, beginning with the formation of the state in Burma.

\section{State Formation, "Preclassical" Burma, and Indianization in the Early Urban Period}

Although the subject of state formation is too complicated an issue to deal with properly here, ${ }^{1}$ certain issues in it need to be raised because the Mon Paradigm has shaped conventional thought on the subject with regard to both Burma and Mainland Southeast Asia. By having made coastal Rāmañnadesa the earliest kingdom in both Burma and the region-dating it to before the first millennium AD_the Mon Paradigm has, in effect, credited the origins of the state in Burma with the Mon of Lower Burma rather than the Pyū of Upper Burma. This, in turn, implies that the state in Burma was ultimately based on the commerce and trade of the maritime world rather than the agriculture of the interior.

Yet, Rāmaññadesa does not appear until seventeen centuries after the earliest dated complex urban settlements (the basis for the state) had already emerged in Upper Burma's Dry Zone, the foundations of whichthe prehistoric stone and metal cultures-are also located in the agrarian interior of the country, not on the commercial coast. The evidence from Upper Burma suggests a geopolitical, economic, and cultural connectedness between the stone and metal cultures of the interior and the subsequent urban settlements built nearby or in some cases over them, and ultimately also with the "classical" kingdom centered at the walled city of Pagán, which was built only yards from some of these earlier settlements.

In contrast, the few urban communities that have been discovered on or near the coast cannot be dated securely, but certainly not earlier than those found in the interior. Nor is there evidence of prehistoric cultures on the coast that can be said to predate those in the interior. Moreover, the consensus among today's Burma prehistorians is that even such Lower Burma cultural remains as there are resemble more the urban societies of the Tibeto-Burman-speaking Pyū culture of the interior than any other cultural group. The evidence suggests, therefore, that these coastal urban sites 
were the frontier appendages of a relatively similar, if not uniform, interior agrarian civilization, rather than the nuclei of an earlier and different, coastal one, whether Mon or otherwise, with the commercial wherewithal to have begun the process of urbanism and state formation in the area. The absence of any state infrastructure or its foundations in Lower Burma prior to the formation of the state in the interior allows us to challenge both the conventional view that maritime trade was the basis for state formation in western Mainland Southeast Asia in general, ${ }^{2}$ and more specifically, its applicability to Burma, with the Mon as primary actors.

After the emergence of polities in the interior, the evidence for Dry Zone Paramountcy as the normative pattern in Burma's history thereafter is overwhelming: a densely populated, well-irrigated, highly predictable, and productive agrarian interior dominated a much later-developing, sparsely populated, monsoon-dependent trade and monocrop culture of Lower Burma for approximately two millennia. Although this does not mean that the coastal world played no significant role in the process of state development in Burma, it does suggest that this role came late and was irregular and marginal, comprising approximately 217 intermittent years out of a total 2,100 nearly unbroken years in the urban history of Burma. ${ }^{3}$

And because in Southeast Asia generally, domesticated agricultural production (especially of rice) also seems to have spread from north to south, ${ }^{4}$ from the interior of the Mainland to its coasts, we have to wonder whether an initial pattern of agrarian-based state formation was not the norm rather than the exception. My guess is that the development, expansion, and regularizing of rice production itself was the ultimate basis for the subsequent growth of trade on a statewide scale, so perhaps a distinction needs to be made between what anthropologists call "primary" and "secondary" state formation, especially in Mainland Southeast Asia where agriculture was the basis for the former, and trade, for the latter. Of course, a third scenario is also possible, in which state formation was occurring in both locations: in the interior as well as on the coasts, either simultaneously or nearly so. But in Burma, the evidence for state formation in the agrarian interior clearly precedes that for the coasts by over a millenium.

Inasmuch as trade and commerce were unlikely candidates for the genesis of primary state formation in Burma, so also was the role of merchants and traders in it. This is not to say that traders and merchants had nothing to do with secondary state formation in Burma, but the earliest extant written texts suggest that a much more important role was played by a different class of people in primary state formation, particularly those well versed in the sometimes esoteric, certainly sophisticated literature of India. This was unlikely to have been within the normal expertise or self-interest of the 
ordinary trader and merchant. The earliest written evidence in Burma and the implications of other kinds of data such as iconography, inter alia, imply the influence of an established literate class of people whose professions were not likely to have been in trade and commerce but in the pursuit of "orthodox" ideology.

It could be countered that the environment of the coastal world, with its higher rate of rainfall, humidity, and so on, accelerated the deterioration of evidence. However, like the rest of the Mon Paradigm, this argument rests on the absence, rather than the presence of evidence, a flawed methodology that allows one to prove or disprove anything one wants. Besides, if the geographers are correct that the deltas of the major rivers of Mainland Southeast Asia have increased at the rate of several meters a year, ${ }^{5}$ the material remains for that alleged coastal genesis should exist on land today, not submerged in water. And even if evidence of this kind of settlement is found between the coasts and the interior-for example, as at Angkor Borei recently ${ }^{6}$ - the cause and effect relationship between such settlements and the formation of the (in this case, Angkorian) state, still needs to be demonstrated. It is not just a matter of presumed vanished evidence but one of not having shown the putative consequences of it.

There is no contemporary evidence on or near the coast of Lower Burma for anything remotely resembling a polity or even its foundations prior to the expansion of the interior cultures into that region. In the agrarian interior, to reiterate, Beikthano appeared nearly seventeen centuries before the first Lower Burma polity or kingdom, Śrì Kṣetra over eight centuries before, and Pagán more than six. The problem has been further obfuscated and complicated by linking the processes of state formation in Lower Burma to an ethnicity-the Mon. This is entirely spurious. Not only does the evidence show that Burma for nearly the entire first millennium $\mathrm{AD}$ is without a Mon-speaking population, but the coastal areas said to have been Rāmaññadesa were, at that time, an undeveloped, sparsely inhabited frontier region except for the few scattered urban settlements perhaps inhabited by a variety of different cultures. Can the currently dominant maritime, trade-centric, ethnic approach to state formation in Southeast Asian studies live with the paradigm shift I am proposing?

The subsequent development of complex urban centers-that is, the "preclassical" stage in Mainland Southeast Asia-is also pertinent. It has been chronologically, conceptually, and institutionally connected to the process of "Indianization," the first phase of which is usually dated to the first several centuries before and after the first millennium AD. ${ }^{7}$ What this means is that Indianization has also been linked to mythical Rāmaññadesa, with numerous ramifications not only for Burma but for the rest of Southeast 
Asia. Indic art forms, writing systems, literature, and conceptions of the state and leadership were thought to have gone through a coastal, Lower Burma Mon cultural prism before they went elsewhere inland.

In Burma the hard evidence does not support such a scenario; in fact, it is just the opposite. Indic influences infused with the kinds of ideologies and concepts likely to further stimulate state development moved in the same direction that state formation did: from north to south, from the interior to the coast, from agriculture to commerce, and from Tibeto-Burman to Austro-Asiatic speakers, not the other way around. Although later waves of Indian influence did come from the coast-perhaps as part of a secondary state-formation process - by that time the synthesis of indigenous foundations and direct Indic contributions among the Pyū of Burma were already well established.

The political and religious ideologies found in Buddhist texts attributed to Rāmaññadesa and Lower Burma-such as the Tipitakas and the Jätakas - should be returned to the places where they first appeared, Srì Kṣetra and Pagán, which had acquired them directly from either India or Śrī Lan்ka. So should other Indic traditions of patron-saints, especially those pertaining to Gavampati, Upagupta, and Maitreya, along with indigenous conceptions framed in Indic formulae such as the Cult of the 37 Nats. There is no evidence that Indianization of the Pyū and Burmese cultures had anything at all to do with the Mon and certainly not with the nonexistent Rāmaññadesa.

The supposed Indianization of Rāmaññadesa in Lower Burma as early as the first century AD also raises serious problems for some of the history of early Southeast Asia. In particular, it affects Dvāravatī, and by so doing, affects several other polities and cultures of Mainland Southeast Asia said to have been build on, or at least influenced by that culture. ${ }^{8}$ This first putative Old Mon center (kingdom, culture, polity, "imagined community") in Southeast Asia, thought to have arisen in the sixth century AD, appears to have "declined" by the end of the ninth when written Dvāravatì Old Mon disappears in epigraphy. ${ }^{9}$ Because the corpus of Old Mon inscriptions found in Thailand and Laos shows that the oldest ones lay in Thailand's central plains, it is thought that Dvāravatī's center was also there. Wherever its exact location, the Mon Paradigm assumed that it was the source of Burma's Mon culture, which ostensibly makes its first appearance at Thatôn. ${ }^{10}$

However, the alleged connection between Lower Burma and Dvāravatī cannot stand up to scrutiny as shown in Chapter Seven. Besides, dating Rāmaññadesa to before the first millennium AD places it a good 600 years prior to the beginning date given to Dvāravatì itself! How could Dvāravatī be the source of Mon culture for Rāmañnadesa if it comes later? Moreover, this 
early dating of Rāmañnadesa implies that it was the source of Dvāravatī's Indianization, and, by extension, of subsequent western Mainland Southeast Asian polities as well. I seriously doubt any scholar of early Southeast Asia would agree that Lower Burma was the ultimate source of Indianization for the rest of Mainland Southeast Asia.

\section{Pagán, the Development of Lower Burma, and the Birth of Rāmañnadesa in the "Classical" Period}

During the first millennium AD, when Rāmañnadesa was said to have flourished, it is not even certain that the area where its center, Thatôn, was claimed to have been located was not under the ocean. The shoreline at the end of the first millennium was much farther inland, as studies on the Bay of Thailand attest. ${ }^{11}$ And even if most of Rāmañnadesa were not under the ocean at the time, there still may not have been enough land on which to build the kind of major kingdom or center implied by the myth of Rāmañnadesa, since the west coast of the Tenasserim Peninsula is what Michel Jacq-Hergoualc'h calls a submergence coast. He writes that "the sea has penetrated deeply into the mountains, creating certain types of fjords or abers... limiting the coastal plains to a thin strip of earth somewhat enlarged over the centuries by alluvial deposits. . .."12 The relatively small hinterland of these coastal areas probably could not have sustained the population of a kingdom the size and scale of Rāmañnadesa implied by the Mon Paradigm. Thus, although Lower Burma may not have been a total wilderness, it was nonetheless not nearly as urbanized or populated as the Dry Zone was at the same time, and certainly not as economically, politically, or culturally advanced. If some Mon speakers and others had migrated into Lower Burma sometime before Pagán developed its infrastructure in the mid- to late eleventh century down there, it was probably involuntary: that is, "push" factors caused by one or more epidemics, along with the decline of their civilizations, and/or Khmer and T'ai expansion and pressure, rather than any particular attraction that Lower Burma had to offer.

At the end of the eleventh century, however, the situation had changed as Pagán expanded into and developed the frontier region of Lower Burma. Having already consolidated its power in the north, east, and west, King Aniruddha and King Kyanzittha advanced toward and took Lower Burma. Had there been any Old Mon speakers present already, it was probably during these campaigns, especially Kyanzittha's, that they were taken back to Pagán. Perhaps this is the historical basis for the myth of the conquest of Thatôn.

Subsequently, probably during the reign of Alaungsithu, Kyanzittha's 
successor, Old Burmese speakers from Upper Burma were being settled in Lower Burma as well; it was not just a one-way movement. They probably first occupied the urban sites left by the Pyū or the towns and villages that were already part of the local scene. The rest of them seem to have been created by the Pagán kingdom during the next two centuries, for their names are found written first in Old Burmese, centuries before they were duplicated in Middle Mon belonging to the fifteenth century.

This infrastructural development of Lower Burma probably occurred late in the eleventh century after the region had been conquered and placed under the authority of crown governors and local leaders appointed by the center, presumably enforced with garrisoned troops. It was the development that followed this "pacification," more than epidemics or battles, that stimulated Lower Burma's commercial, political, socioreligious, and demographic growth. The evidence seems to suggest, therefore, that it was Pagán's own growth and development in Upper Burma that was initially responsible for the subsequent establishment of a state infrastructure on the coasts of Lower Burma that finally culminated in the country's first Mon state in the late thirteenth century.

As the only exemplary center in Burma between the eleventh and the thirteenth centuries with the ability to attract and absorb an influx of people in economically and culturally meaningful ways, Pagán would have provided the "pull" factor that subsequently drew people to Upper Burma, including the Mon speakers. The magnificent capital and surrounding countryside offered cleared and irrigated fertile land to cultivate, a stable and peaceful society, and good employment opportunities in numerous sectors. The most economically attractive of these industries must have been the arts and crafts, part of the huge temple construction economy, with numerous related businesses and occupations. Brickmaking and masonry; gold, silver, and bronze craftsmanship; wood carving and carpentry; ceramics; animal husbandry; sugar palm extraction; bee and honey horticulture, were all industries and occupations directly related to temple-building. In addition to the actual construction of nearly 3,000 religious edifices during a span of approximately 300 years, all these buildings would have needed regular maintenance thereafter, providing a sustained demand for skilled and unskilled labor well beyond the Pagán period. Indeed, it still does today, as illustrated by the many businesses that depend on Pagán's existence, even if as a modern "pilgrimage" (tourist) site.

The need for skilled craftsmen is obvious in the repair of religious buildings. But unskilled labor was also needed as lay guardians of temples and monastic lands. These individuals would often be given land or its use and/or a share of its output, in return for services. Numerous other professions not directly related to construction benefited from temple-building 
and temple maintenance as well. These were the accountants, bankers, and scribes, who were indispensable for protecting and preserving the legal records of what amounted to perpetual tax-free religious property.

A similar demand could be found in the military sector, as Pagán expanded its hegemony. Crown soldiers were settled on premium irrigated crown land or in some instances in uncultivated areas that later became valuable crown land. They were given rights "to eat," "to live on," and "to work" these lands. Military service offered high status and political mobility upward all the way to the ministerial level at court, where the highest officers served the king. Both the religious and military sectors, therefore, had a direct affect on demographic growth, the expansion of agriculture production, and other components of the economy. And finally, Pagán financed and in other ways supported a regular, exciting social, religious, and state pageantry, based on a combined Indic and indigenous culture that was surely familiar and appreciated by all. ${ }^{13}$

Since Pagán paid its labor, especially the artisans and skilled craftsmen -in gold, silver, paddy, land, rights to land or produce, and other valuable items, such as elephants, boats, and horses-monumental temple-building was a major stimulus for economic development, creating opportunities not readily available elsewhere in the region at that time, perhaps with the exception of Angkor. But whether Angkor's artisans and unskilled labor were paid in cash (or convertible valuable commodities) to make it another nucleus of economic development during the same time is not entirely clear. $^{14}$

It was economic growth in Upper Burma, therefore, that attracted people to and from Lower Burma, a voluntary movement that had little or nothing to do with wars or disease. Lower Burma's population probably consisted of Rmeñ, Tamil, and others collectively known by then as Tanluin in the Old Burmese sources, including the people the Chinese called Kunlun, who supplied the steady demand for demographic resources important to the growth of the kingdom of Pagán, which, like most of the "classical" states in Southeast Asia, was short of labor. ${ }^{15}$ The variety of influences found in the art and architecture of Pagán and the evidence in the Old Burmese inscriptions of this period demonstrate that people of many linguistic and cultural backgrounds lived and worked there, especially during the period of growth and efflorescence of the twelfth and thirteenth centuries.

Not only was Pagán's economy a tremendous socioeconomic magnet, the timing was also good. Pagán's temple construction occurred during a period of time when Dvāravatī, Śrì Vijaya, and the Coḷ empire had already experienced political and economic decline, so it would have attracted migration from such societies. Indeed, the economic situation at Pagán 
would have provided the kind of stability and employment opportunities that attracted most people, whether or not they were displaced and unemployed. To reiterate, it was Pagán's growth and development in Upper Burma that was in turn responsible for the growth and development of Lower Burma itself, on which the emergence of the first Mon state in Burma was based.

The lateness of this development of a Mon kingdom in Lower Burma frees Dvāravatī scholarship from having to explain an earlier Old Mon center in Lower Burma. Indeed, Dupont's doubts about the existence of an early Rāmañnadesa probably arose precisely because he was studying Dvāravatī. Now its data can be evaluated and interpreted without considering Lower Burma at all, and this will undoubtedly lead to new interpretations regarding Dvāravatī.

By the late thirteenth century, while the kingdom of Pagán was being harassed by the Mongols, Wareru (Magadu) of Martaban (1287-1296) seized the opportunity to establish the nucleus of an independent polity by attempting to take over the entire Lower Burma region. In the earliest Mon texts of Burma, Wareru is indeed featured as the founder of the Mon state in Lower Burma. But neither this endeavor nor another about ten years later succeeded totally, for a near-contemporary inscription at Pagán records the rewarding of one of its generals with land for "victory in the War at Dala" (near modern Yangôn) that occurred in the early 1290s. Despite the long-term effects of the drain of tax-exempt wealth to the sangha and pressure on its northern borders by one of the most powerful forces in history, the kingdom of Pagán still had enough power to assert its hegemony on the coast.

That, however, may have been its last hurrah. A decade earlier, in 1281, the kingdom of Haripuñaya was taken by the forces of King Mangrai of Sukhodaya. This likely triggered a mass exodus of Mon speakers to Lower Burma, perhaps to Pegu. It might have been their best option, for Pegu was a city with whose culture and language the Old Mon speakers of Haripunjaya were already familiar, and where kinship and other networks already existed, as is suggested by the later Northern Thai chronicles. For the first time, then, Lower Burma of the mid-1290s had the demographic resources to effect the rise of an independent kingdom led by Mon speakers. And it also had the physical and conceptual infrastructure, built by Pagán, on which to do so.

What is compelling about the "fall" of "Mon" Haripuñaya in the development of a "Mon" Rāmañnadesa is that it occurred just two decades before a Chinese source for the first time in 1298 mentions an embassy sent from a "new Teng-lung kingdom" in Lower Burma. That act of independence coincides with several other events favorable to the establishment of a sep- 
arate state in Lower Burma: the final weakening of Pagán caused by the continued drain of taxable wealth to the saingha, the resulting factionalism at the Pagán court (culminating in the ascendancy of the famous Three Brothers who began to carve the kingdom into three parts), and the pressure by the Mongols on the northern frontier. ${ }^{16}$ All these factors contributed to the birth of historic Rāmañnadesa and occurred only towards the end of the thirteenth century, approximately thirteen hundred years after Rāmañnadesa was said to have first emerged.

Whether this Rāmaññadesa was composed entirely of Old Mon speakers is uncertain, for even Wareru himself is said in some western sources to have been a "Shan adventurer," or at least knowledgeable about the T'ai language. ${ }^{17}$ His link to T'ai speakers explains, in part, why Hamsavatī, the formal Pali name for Pegu, was considered a tributary of Sukhodaya in King Ram Kamhaeng's inscription of 1292, for, as we have seen, Wareru's mythology included his fleeing Sukhodaya to Lower Burma with a daughter of the king, whom he then made queen. Whatever historic Rāmaññadesa's main ethnic makeup, it was certainly Lower Burma's first independent kingdom.

\section{The Crisis of the Thirteenth Century}

Another important, long-held, and unresolved issue is known in the field as the "crisis of the thirteenth century." It was said to have been caused in part by the Mongols, who were thought to have sacked the capitals of the great "classical" kingdoms, thereby creating a new age with new centers of power significantly different from the old. And in part the crisis is also linked to the establishment of Theravāda Buddhism, a religion said to belong to the common people which therefore challenged the elitist Hindu-Buddhism of the "old Indian kingdoms," thus contributing to their decline. The Mon Paradigm is relevant here in numerous ways.

First, the role attributed to the Mongols in this "crisis," at least in terms of Pagán, has already been demonstrated elsewhere to be totally erroneous. ${ }^{18}$ To be sure-although neither the proponents of the "crisis" nor of the Mon Paradigm saw it-the turmoil created by the Mongols in Upper Burma may have accelerated the emergence in Lower Burma of historic Rāmaññadesa; but it was not caused by the Mongol raids. Rather, as shown above, that process had begun much earlier and extended over a long period of time. A state infrastructure first had to be built in Lower Burma over a course of several centuries, beginning with the eleventh. That was what attracted the influx of labor into the region, which only by the late thirteenth century had a critical mass enabling it to create a polity independent of Pagán. Thus the Mongols' appearance on the scene around the 
same time helped destabilize the situation in Upper Burma that then provided the opportunity which the founders of historic Rāmañnadesa seized, establishing the first Mon kingdom in Burma.

Second, that Theravāda Buddhism was also responsible for creating this "crisis" is equally questionable. Theravāda Buddhism was not a thirteenthcentury phenomenon, especially in Burma; it can be found as early as seventh-century Śrī Kṣetra for certain, if not even earlier at fourth-century Beikthano, and of course, it was present since the ninth century in Pagán. Pagán, in turn, had established Theravāda Buddhism in what became historic Rāmañnadesa in the eleventh-century. In Thailand, the establishment of "classical" Sukhodaya preceded the Mongol raids of the late thirteenthcentury, and as far as we know, the kingdom began as a Theravāda Buddhist state; it did not replace any previous Hindu-Buddhist state. In all these places the kinds of "egalitarian" doctrines found in Theravāda Buddhism, and claimed to have caused the decline of the "classical" states in the thirteenth century, had long existed.

Besides, Theravāda Buddhism "belonged" as much to the elite as to the commoners, so it was not a matter of replacing the existing conceptual system of the old Hindu-Buddhist kingdoms by a process Lawrence Briggs has called "superbolshevism." ${ }^{19}$ Although it is true that he was speaking mainly of Angkor, he still held Theravāda Buddhism as an ideology accountable for this class "revolution." But, as I have shown elsewhere, the long-term economic effects of the merit-path to salvation, found in Theravāda Buddhism and embraced by both elite and commoner, was what created the structural conditions for the decline of the Burmese state; it was not a class and ideological struggle between Hindu-Buddhist elite and Theravāda Buddhist commoner. Pagán's decline, and probably that of several other "classical" states had little or nothing to do with a grassroots movement of Theravāda Buddhist commoners fighting the tyranny of the elite class of Hindu-Buddhists. That was twentieth-century western egalitarian and revolutionary wishful thinking.

Indeed, the rise of post-Pagán Ava in Upper Burma and historic Rāmaññadesa in Lower Burma was less a revolutionary event that overthrew the old system and its principles than it was their resurrection, for structurally and ideologically both new polities were Pagán writ small. ${ }^{20}$ Although they marked the beginning of a new era, they were not challenges to an old order.

But because l'histoire événementielle, often synonymous with linear change and progress, was very much a part of the western reconstruction of early Mainland Southeast Asian history, crises and upheavals became causal agents of that change and progress. If we remove this crisis-seeking, linear 
approach to structural change, however, the revolutionary character in the "decline" of the "classical" states of Mainland Southeast Asia takes on a more evolutionary quality, caused less by dramatic, externally generated events than by internal, structural contradictions. ${ }^{21}$ It is more this evolutionary process, and less a revolutionary break with the "classical" past, that was instrumental in the making of the "postclassical" period. Both Ava and historic Rāmañnadesa were legacies of Pagán, not new products created by Mongol invasions or the superbolshevism of Theravāda Buddhism.

\section{The "Postclassical" or "Early Modern" Period in Burma}

By the beginning of the fourteenth century, the kingdom of Pagán had split into three centers-Pinya, Sagaing, and Myin Saing, ruled by the famous Three Brothers. Around the 1330s the last king of the Pagán dynasty had died, and in 1364 Ava emerged as the preeminent nucleus of power in Upper Burma, having reunited the dispersed human and material resources left there by the decline of Pagán. But as the center of gravity had shifted approximately ninety miles north of the old capital-in order to address what its new leaders perceived was a bigger threat, the Ming-Lower Burma became less of a priority and also less accessible than it had been under the Pagán Dynasty.

The weakening of Upper Burma's grip on Lower Burma enabled Binnya U, a successor of Wareru, to finally make Pegu the uncontested capital of Lower Burma. It was only during this First Ava Period-fourteenth to the early sixteenth centuries AD—-that original dated evidence first appears in Lower Burma that documents the development of a sizeable, fairly wellintegrated polity where the leadership and the center's lingua franca was now, and for the first time, clearly Mon. Ironically, then, the emergence of Ava and Rāmaññadesa was possible because of Pagán's decline in power on the one hand, but also, on the other, because of its legacy, built as they were on its demographic, physical, and institutional infrastructure.

Binnya U's famous descendant Yazadarit (1385-1423) kept Ava's ambitions confined to Upper Burma for several decades, despite many attempts by its kings to resurrect Pagán's hegemony on the coast. Occasionally Ava managed to conquer some of the port cities of Lower Burma, but Yazadarit always managed to take them back. Ultimately, a modus vivendi was reached between Ava and Pegu, and the two centers lived in peace for nearly a decade, a truce secured by the marriage to the king of Ava of one of Yazadarit's daughters, who was to become a famous queen in Lower Burma's history.

This was the celebrated Shin Saw Bu (1453-1474). After having spent several years of her life as a queen at Ava, part of the conditions for the 
truce, she ultimately escaped to Lower Burma with the help of two monks. Subsequently, she succeeded to the throne of Pegu after two successors of Yazadarit had reigned and became the second of only two women sovereigns in the history of the country. ${ }^{22}$ After her long, peaceful, and prosperous reign in Pegu, she was followed by King Dhammazedi (1472-92), one of the monks who had helped her escape, who, by then, had shed his saffron robe. He was said to be her "son" in his Shwédagôn Pagoda Inscription but was actually her son-in-law, having married her daughter.

During his reign Pegu attained the pinnacle of its stature as the most powerful kingdom of the Mon in Lower Burma, and it was only then that Dhammazedi invented the tradition of an "earlier" Thatôn. In doing this, Dhammazedi established a fictive genealogical continuity between Thatôn and his own Pegu, replacing their actual historic and cultural ties to both Upper Burma and Thailand with a legendary, coastal Lower Burma Mon culture instead. It was this fifteenth-century reconstruction (and perspective) that was so enthusiastically embraced and perpetuated by colonial officials and scholars, in part because it was inscribed on sacrosanct stone, but also because they desired to see an ancient Mon kingdom in Lower Burma, which justified certain military objectives of the First Anglo-Burmese War. Once accepted by colonial scholars, "the legend that was Lower Burma" secured its place in the study and writing of Burma's history.

Unfortunately, the acceptance of an earlier, mythical Rāmañnadesa has minimized the contribution made by the Burma Mon of historic Rāmaññadesa to the history of "postclassical" Southeast Asia. Partly because the legendary stature of mythical Rāmañnadesa has weighed so heavily on the assessment of historic Rāmañnadesa, the latter, invariably, has been found wanting. As a result, scholars have tended to favor the importance of mythical Rāmaññadesa and have given far less time and effort to the reconstruction of historic Rāmañnadesa. Now, however, without the Mon Paradigm, historic Rāmaññadesa's significance to Burma and Southeast Asian history can be more insightfully and freely assessed.

Already one such assessment can be made: the contribution by the Lower Burma Mon to the history and culture of Burma during the Ava period (1364-1527) is clearly more important than heretofore thought. It had more than five hundred years (even if intermittent) with which to work. Both linguistics and history should bear me out on this. Similarly, the Lower Burma Mon contribution during the "postclassical" period to coastal activities in the Bay of Bengal, the Gulf of Martaban, and the Straits of Malacca -particularly vis-à-vis Vijayanagara, Ayudhyā, Arakan, and Malacca and their maritime satellites elsewhere in Southeast Asia-is likely to be far more important than any attributed to them during any other period of time, historic or legendary. 
Thus in the history of early maritime Southeast Asia, the significance and impact of the Burma Mon lies not during the "classical" period when Śrì Vijaya, the Coḷas, and the Śrì Lañkans were the premier powers, but during the "postclassical" period when the Ming, the Spanish, the Malays, the Indians, and the Portuguese were the dominant players. In the history of early Mainland Southeast Asia as well, the Burma Mon contributed most to the period when Ayudhyā and Ava were dominant, not when Pagán and Angkor were the main centers of power. This totally different picture, made possible only by removing the Mon Paradigm, should be the basis for any future assessment of the Mon people and culture of Lower Burma.

In 1539 this relatively new and short-lived Mon kingdom of Rāmaññadesa was conquered by an Upper Burma power initially centered at Toungoo, a city on the edge of the Dry Zone and once a provincial seat of Ava. The Toungoo leaders saw Pegu's strategic potential as a commercial center and moved their capital there, rebuilding and enlarging it so that it later became the capital of the entire country. Under the Toungoo rulers, ${ }^{23}$ Pegu was even more involved in the trade and commerce of the "long sixteenth century," ${ }^{24}$ particularly in the region around the Gulfs of Martaban and Thailand, the Kra Isthmus, the Bay of Bengal, and the waters of Island Southeast Asia, not to mention the Gulf of Mexico and the Pacific coast of California. ${ }^{25}$ Pegu became the premier center of all western Mainland Southeast Asia for the next sixty years, when it conquered Chiang Mai, Ayudhyā, and Vientiane, at the time the major regional centers of power.

But this empire was no longer the Rāmaññadesa of Shin Saw Bu and Dhammazedi, but of Tabinshwehti and Bayinnaung, Burmese speakers from the Dry Zone of Upper Burma. Like others before and after them, these new rulers invited local Mon talent to their court, such as Bannya Dala who wrote the Yazadarit. Thus Mon-led Rāmañnadesa had already ceased to exist by the first quarter of the sixteenth century. Its "golden age" had amounted to only some 200 years out of a total 1,500 years dominated by agrarian, inland, Dry Zone Burma. It was the new, sixteenth-century Burmese-Mon Rāmañnadesa (although it was not called that) that western scholarship remembers best, partly because this was the entity described in many of the earliest firsthand western-language accounts.

In 1599, just sixty years after Pegu was taken by the Toungoo rulers, the once-preeminent center of western Mainland Southeast Asia was burnt to the ground by the new coastal power of Arakan, centered at Mrauk-U, a destruction completed by the later arriving forces of another coastal power, Ayudhyā. ${ }^{26}$ Well before that event, however, by 1555, Pegu's leaders had already regained control of the demographic and agrarian resources of Upper Burma, so that the destruction of 1599 only accelerated their antic- 
ipated move back to Upper Burma and to a way of life with which they had always been more comfortable. They returned to a familiar human and physical landscape where the heart of Burmese culture lay, with its myriad temples and monasteries, monks and lay supporters, its artists and their crafts. This was where most of the history of Burma had been made. The old city of Ava was rebuilt to serve as the capital of Upper Burma under the Second Ava Dynasty (also called the restored Toungoo Dynasty by western historians).

Shortly after the Second Ava Dynasty had begun to successfully exert its authority over Lower Burma, Lower Burma reconstituted itself as a viable center of power. Pegu was rebuilt as its seat of power and authority, so that by the first quarter of the eighteenth century the situation was not unlike that from the late thirteenth to the mid-fifteenth century, where two more or less equal centers of power faced each other, one inland and the other coastal. By the middle of the eighteenth century, Lower Burma had regained much of its old wealth and power, having once again become involved in the maritime trade and commerce of the seventeenth and eighteenth centuries, which was in part stimulated by the arrival of more Western powers in Southeast Asia. Pegu's location was still ideal, and it grew into a power that could now contest that of Ava. Lower Burma once more became independent of Upper Burma, and it seemed as if the glory days of Yazadarit, Shin Saw Bu, and Dhammazedi had returned, although this time English, French, Italian, Portuguese, Armenian, and other Europeans were also involved in Pegu's reemergence.

In 1752, for the first time in Burma's 2,000-year history, an independent, coastal Burma power defeated its agrarian counterpart when Pegu took Ava. But Pegu was not seriously interested in unifying the country-it wanted mainly to preserve its economic way of life untrammeled by the Dry Zone powers. Its real competitor was now maritime commercial Ayudhyā, not interior agrarian Ava, so it neither established Ava as its capital, nor did it move the bulk of its population and other resources there. Instead, it left a governor to administer Upper Burma and returned to the coast with Ava's entire court, its ministers, books, and treasures, in effect, its regalia for legitimacy. ${ }^{27}$ Uncomfortable in the Dry Zone and its conservative agrarian way of life in any case, the coastal invaders wanted to return to the more exciting "international" environment of the maritime world.

That decision was crucial, for it allowed Upper Burma to once more reconstitute itself and set the stage for the last Dry Zone dynasty, the Kônbaung, which rose from the ashes of Ava to reunify the country for the last time under the Burmese monarchy. Whereas the agrarian world seemed to need and want to control the revenues of the coastal world, the reverse, for 
the most part, was not true. The coast was satisfied with trading for the interior's food supplies and other commodities. It had no desire to live there, farm the land, and produce the crops needed. When in 1757 Upper Burma under Alaungpaya took Pegu and reunified the country for the last time, Lower Burma once again became part of a unified kingdom centered in Upper Burma, thus returning to the pattern begun by the Pyū in the first millennium AD. The political and cultural center of the country remained in the Dry Zone for nearly 130 more years until the British finally annexed it. As trade and commerce grew during the nineteenth and twentieth centuries, the epicenter of the country once more returned to Lower Burma, where it remains to this day. ${ }^{28}$

\section{The Reification of Ethnicity and Colonial Historiography}

For all these known events in the precolonial history of Burma, one cannot find indigenous, contemporary evidence that any of them were caused by ethnicity; most, if not all, were the result of power struggles among the elite and their clients, sometimes complicated by external invasion and interference, but based mainly on geopolitical, religious, and economic concerns. Indigenous texts such as the Yazadarit Ayedawpon characterize the tension between the First Ava Dynasty and Pegu (exemplified by their respective kings Mingaung I and Yazadarit), not as an ethnic conflict between a Burman and Mon king, but between two strong, equally Buddhist, equally legitimate leaders who ruled two different geopolitical regions of the country. More than anything else, the chronicles were concerned with who was purer in terms of promoting Sinhalese Buddhism. And in the romanticized story of Minguang I and Yazdarit, when one died, the other was said not only to have shed tears but to have died very shortly thereafter, with the clear suggestion that although they may have been contestants they were also soul mates. ${ }^{29}$ Even if allegorical, the story hardly suggests a worldview centered on reified ethnicity, or if empirical, of a history depicted as a perpetual struggle between Burmese and Mon speakers. ${ }^{30}$

The same can be said of Alaungpaya and his major adversary, the king of Pegu, Binnya Dala. The history surrounding Alaungpaya's conquest of Lower Burma and reunification of the country-which colonial scholars claimed was perfect evidence of ethnic conflict for it was allegedly intended to exterminate the Talaing-was anything but that. A closer examination even of Alaungpaya's edicts directed specifically at the people of Pegu and their king as part of his campaign against them does not support any such interpretation..$^{31}$

Out of the ninety-nine edicts of Alaungpaya that have survived, fewer 
than ten were directed at Pegu during his campaign. ${ }^{32}$ Of these, only one, and composed in Pali verse at that, was a direct reference to the Pegu king and his followers whose character was impugned because they were Talaing. ${ }^{33}$ Even in this case, most of the people would not have understood the Pali verse. This single instance, whose target audience was either the court and king or its monks, surely cannot be construed as evidence that Alaungpaya was waging a campaign of extermination against the Talaing people of Lower Burma.

The other nine edicts, written in Burmese and presumably meant to be comprehensible to the majority of the people, focused on Alaungpaya's role as a great Buddhist king, a cakkavatti, who would conquer the world by spinning his disk, the cakra, not because of his superiority as a Burman king. Nor did Alaungpaya state that the Pegu king was weak because he was Talaing; rather, he was weak because of his karma, while Alaungpaya was strong because of his. Alaungpaya also claimed to have Sakka's support, ${ }^{34}$ wielded his weapons, and was about to achieve a dhammavijaya or righteous victory. ${ }^{35}$ He thus attempted to persuade the people of Pegu to surrender because of such Buddhist principles. If the issue were ethnicity, why were such religious principles even invoked?

Apart from this negative campaign waged via palm-leaf dispatches, Alaungpaya's actual behavior also contradicts the conventional colonial view that ethnicity was the main reason for this war. The band of soldiers that Alaungpaya selected to secretly penetrate Pegu, mix with the population and remain apart from each other until the given signal, when they were to attack the palace, ${ }^{36}$ surely would not have been even considered, much less deployed, had there been a general sense that a noticeable physical difference existed between Talaing and Burman, the ultimate basis for reified ethnicity. Indeed, it tells us that ethnicity was never an issue. ${ }^{37}$

Furthermore, the Pegu monarch was always addressed in Alaungpaya's edicts as "the king of Hanthawaddy," not the "Talaing king," while the latter's replies were always addressed to "Alaungmintaya, king of Ratanasingha [Shwebo]," not "the Burman king." ${ }^{8}$ This was public, formal recognition of a geopolitical contest between coastal Hanthawaddy and interior Shwebo, not an ethnic one between Burman and Talaing.

Alaungpaya also refrained from using the word Talaing in a disparaging manner, even in situations most suited for doing so. Replying to a Captain Baker, who had told him that an alliance with the East India Company would benefit the king in all future rebellions, Alaungpaya retorted:

“. . . have I asked? or, do I want any Assistance to reduce my Enemies to subjection? let none conceive such an opinion? have I not, in three Years time, 
extended my Conquest three Months journey on every Quarter, without the help of Cannon, or Muskets? Nay, I have with Bludgeons only, opposed and defeated those Peguers, who destroyed the Capital of this Kingdom; and took the Prince prisoner; . . . don't talk of Assistance, I require none, the Peguers I can wipe away as thus" ${ }^{99}$ [drawing the palm of one hand over the other].

Then he added that he could "crush 100 such as the King of Pegu," without any reference to his ethnicity. ${ }^{40}$

It is true, however, that Alaungpaya played the Burman ethnic card, ${ }^{41}$ but that was because most of the population were Burmese speakers and thus was to his military and political advantage. It does not mean that his goal was one of ethnic cleansing or that the cause of the conflict was ethnicity. He also did not target any other ethnic group, such as the Chin, Shan, or Arakanese, who were loyal to him, but only those who opposed him, which happened to be the Lower Burma Talaing. This suggests a power struggle in which patron-client ties were also very much part of the picture. Playing the Burman ethnic card, then, was an immediate strategy of psychological warfare meant to help accomplish the king's long-term political goal: the unification of Burma.

Thus the history of Burma, especially between the sixteenth and eighteenth century, cannot be depicted as an endemic ethnic battle between Lower Burma Talaing and Upper Burma Burman. Much like the fourteenth and fifteenth centuries, the former period witnessed a struggle for hegemony between the agrarian interior and the commercial coast in which several ethnic groups, in patron-client relationships to the dominant elite, were involved, with religious purity and legitimacy as the ultimate ideological rationale.

But colonial historiography nevertheless conceptualized Alaungpaya's (and also Aniruddha's and Bayinnaung's) reunification of Burma as mainly an ethnic issue. In Alaungpaya's case at least, that led to the erroneous myth of the "downtrodden Talaing," which was then projected backwards on nearly a millennium of Burma's earlier history. An invariable cause-andeffect relationship was created between ethnicity and major historical events since antiquity, so that all of Burma's history indeed looked like a continuous ethnic struggle that had endured until modern times. This ethnic interpretation of Burma's history-central to the Mon Paradigm-remains the dominant historiographic framework for the analysis of precolonial, colonial, and postcolonial Burma. Today's belief in the presence of inherent, and enduring ethnic animosities in Burma stems from this colonial construction, a topic that certainly needs to be reassessed. As a start, the following alternative should be considered. 


\section{Upstream-Downstream: A Geopolitical and Economic Approach}

This twentieth-century ethnic framework of Burma's history conceptually divided the country into static ethnic zones, in which were placed discrete ethnic groups with seemingly impregnable physical, mental, social, and cultural boundaries. Thus as abstract and intangible a concept as ethnicity was used to reconstruct something as concrete and physical as a map, as if that twentieth-century prejudice somehow represented a twelfth-century geophysical reality (see Figure 1). Notwithstanding this great leap that attempted to reconstruct historical reality from modern "imagined communities," the epigraphic and archeological evidence suggests, instead, that indigenous conceptions of the actual physical space at issue were based on geopolitical and economic, rather than ethnic, concerns.

Lower Burma, the Wet Zone, is and was known at least from Pagán times as akriy, that is, "downstream," the "lower part of a river" (in this case, the Irrawaddy). ${ }^{2}$ "Downstream in Tala" is a phrase found in several inscriptions of the Pagán period and other literary sources for defining Lower Burma. ${ }^{43}$ Even in a sittan of 1581 , Lower Burma is still called "the place downriver." ${ }^{44}$ It was the region south of Prome that was considered to be the end of the Dry Zone and the gateway to both Lower Burma and Arakan province. ${ }^{45}$ Upper Burma, in contrast, was and is generally called anya, a reference to the "upstream" regions of the Irrawaddy, but mainly indicating the Dry Zone. ${ }^{46}$ Consequently, an individual from Upper Burma would be known as anyatha, or "son of the anya region," and hence the term "Anyathian Man" given to Palaeolithic man of Upper Burma by western anthropologists in the 1930s, while someone from Lower Burma would be akriytha, or "son of the akriy region."

The principle that the Irrawaddy defined cultural and geopolitical space was also true for places east and west of it: Sunārparanta was the name given by early Burmese sources to the region north and west of the river, while Tambadipa, the region south and east of it. ${ }^{47}$ Thus the Irrawaddy River, the constant, the fixed marker, defined these geopolitical and cultural regions; little hint of ethnic regions was attached to any of these terms except in the general, ambiguous word tanluin used for everyone in Ussā Paikū. And this geopolitical and economic perspective of Upper and Lower Burma was a genuinely indigenous, early, historical one, not one derived from external observers using their own criteria for measuring and categorizing "the Other." The view Burmese culture had of its homeland, therefore, consisted of two environmentally distinct areas: those living upriver and those living downriver, ${ }^{48}$ those in Dry Zone agriculture and those dealing with Wet Zone maritime trade and commerce. 
By the middle of the Pagán period both regions shared common religious traditions, a common writing system that had become the standard for center and provincial administration, a common vocabulary of political ideology and symbolic dimensions of the state derived from a common Indic and indigenous conceptual system, a common structure of state and society, common principles in a coded civil and criminal law, common styles in religious art, and probably even similar tastes in dress and food.

Of course there would be tension and conflict, particularly of the kind one finds when people live in such close proximity and are dependent on each other economically. And of course there were regional, cultural, and linguistic differences and perceptions of such differences between the people of Upper and Lower Burma, of the capital and the outlying villages, and of those living in the plains and those in the hills. The same is true in any multicultural state or polity with many subparts.

But too often we in the West "privilege" categories of difference, while "deprivileging" categories of similarity. We tend to base our construction of "the Other" on our own historical experiences and parochial views of what we think is a universal truth about humanity, rather than on a closer scrutiny of the primary and preferably indigenous evidence. It is true that differences are expressed in that evidence. But they are infrequent and appear in inchoate form. Perhaps the first example occurs in King Kyanzittha's description of Lower Burma as the "Tanluin kingdom," and another occurs in a more developed form in King Dhammazedi's Kalyani Inscriptions, when he coined the term Rāmañnadesa, the "realm of the Rman."

Yet even these early views of a general regional ethnocultural distinction between Upper and Lower Burma superimposed on the more prevalent geopolitical one do not necessarily imply the kind of absolute ethnic rupture that modern scholars have inferred. Rather, the distinctions were very much concerned with each side's claims to earlier, purer Buddhist origins, and hence to orthodoxy and cultural antiquity. The reason for making these ethnocultural distinctions of what were really geopolitical regions had more to do with religious one-upmanship, legitimacy, and political power than with ethnicity.

Moreover, even if certain regions came to generally represent the habitat of particular ethnic groups, surely such "ethnic space" must have had considerable flexibility and movement. These were not static, unchanging territories with impregnable boundaries forever fixed on a map, for we know Austro-Asiatic speakers settled in Upper Burma, while TibetoBurman-speaking peoples from Upper Burma moved into Lower Burma, and many areas were mixed. The best example of this was Tavoy, a major town located in the midst of the Mon of Lower Burma, whose inhabitants were Burmese, not Mon speakers. 
And because there seemed to have been few strict rules against exogamy in Burma, especially of the kind one might expect in a "caste" society, these different ethnolinguistic groups very likely also intermarried. In elite society as well, political alliances were established between royalty and provincial "aristocracy" belonging to different ethnolinguistic groups and cemented by political appointments and marriage. Shin Saw Bu's case would have been just one of many. The image of an impenetrable block of Mon speakers occupying Lower Burma from time immemorial, which buttressed itself against another block of Burmese speakers in Upper Burma, never or seldom intermingling and therefore experiencing centuries of ethnic conflict, is a twentieth-century, imagined and desired portrait; it is not supported by the evidence.

Encouraged by segments of the colonial establishment, Mon nationalism in the early twentieth century shifted what had been a genuinely academic topic (that should have been resolved academically) into an ethnic one that became entangled in colonial politics and missionary concerns. What had been basically a linguistic and historiographic issue had become a politically charged crusade for ethnic minority rights. In this struggle, a presumably "victimized" Mon population of Lower Burma was depicted as having struggled against an oppressive Burman Upper Burma for centuries. Not only did the prevailing political view effectively disarm any potential academic challenges to it, but the most important scholars in the forefront of early Burma Studies at the time were also of Mon cultural background and seemed rather enamored of the whole thesis.

Thus the political and administrative policies of colonial officials and scholars and the sentiments of their native proteges had reformulated "ethnic relations" into a form that the protagonists themselves had seldom, if ever, experienced in their early history. This external view of ethnic relations in precolonial Burma is truly one seen from the "deck of a Dutch ship," to use C. Van Leur's famous phrase, not one derived from Burma's Dry Zone rivers and paddy fields or its Wet Zone port cities and bazaars.

Then what had been a worldwide call for "national self-determinism" vis-à-vis colonialism between the two World Wars was reinterpreted much more narrowly. The issue was no longer one of indigenous people fighting foreign colonialists but of minority ethnic groups fighting the majority ethnic group within the same nation. The oppressor had been deftly switched from an external, usually western, colonial power to an internal majority ethnic group. And because reified ethnicity was not a viable category of argument, it was replaced with the phrase "local autonomy," a much more credible (and fashionable) concept to advocate than reified ethnicity. Yet much of the "evidence" garnered from history and linguistics to legitimate the colonial legacy of reifying ethnicity and the postcolonial 
rhetoric of privileging "local autonomy" turns out to be exogenous, late, and legendary.

In sum, the historiography of the past century and a quarter has placed a millennium of Upper and Lower Burma relations in a largely binary, dichotomous ethnic framework of Burman versus Mon, ${ }^{49}$ center versus periphery, and majority versus minority, rather than situating these relations in a larger, longer, more encompassing, mainly unified, geopolitical, religious, social, cultural, and economic dualism. It is a major distortion in which the Mon Paradigm has played a crucial part that needs to be rectified.

\section{Conclusion}

If, without the Mon Paradigm then, the history and historiography of the entire precolonial period in Burma can be this different from the conventional one affecting not just esoteric and narrower Burma issues but those as broad as state formation and Indianization in the region, one wonders how different the early histories of the rest of Southeast Asia might also be without their own "Mon Paradigms." For surely, there must be comparable, still undisclosed conventions infecting their historiographies as well, especially as they too were reconstructed largely during the colonial period by officials and scholars who shared similar values and mentalities with those in Burma. That I am not alone in questioning a possible early "Southeast Asia Paradigm" is attested by doubts raised recently with regard to the early existence of Champa in Southern Vietnam, suggesting that there may not have been a unitary state there as well. ${ }^{50}$ And Champa, like Rāmañnadesa, Funan, and Dvāravatī of the "preclassical" period, was thought to have played a similarly fundamental, foundational role in the making of the "classical" states of Southeast Asia. Might not, then, our conventional views regarding the origins of the "classical" period itself, and of the nature of its states, also be wrong?

If so, do we have the time and resolve-some of us are in our twilight years after all-to rectify this and see it all through? If not us, who? Although the next generation of Southeast Asia historians may not be as enamored of these early issues as some of us of the earlier generation are, the intellectual and academic problems of the Mon Paradigm are very pertinent to those current in colonial studies today. Indeed, in many cases, these kinds of issues have been raised and addressed much better by the younger generation-as their education has been thoroughly immersed in them-than by the older generation. The former can probably explain much better the colonial period constructs responsible for some of these "inventions of tradition" than we can. 
But—-to ask the question one more time-can we live without the Mon Paradigm? The answer is we can and we must. For the historical reality is that the Mon Paradigm is a myth: Sona and Uttara had nothing to do with the origins of Theravāda Buddhism in Burma, and perhaps even in the rest of Southeast Asia; there was no Mon kingdom in Lower Burma called Rāmañnadesa that preceded Pagán; there was no conquest of Thatôn by Aniruddha in 1057; and as a consequence Lower Burma did not "civilize" Upper Burma. It was the other way around: Pagán settled, developed, and "civilized" Lower Burma. It was Pagán's economic, political, and cultural development of the interior and its agrarian sector that enabled the subsequent rise of coastal, trade-centered Rāmaññadesa. Like it or not-and notwithstanding my Mon father-the making of "classical" Burma has little or nothing to do with the Mon of Lower Burma. We must come to terms with this old and erroneous sentiment no matter how undesirable this dualistic interpretation of early Burma may seem in today's political world of binary constructs, lest we perpetuate for yet another generation a myth that has been allowed to continue far too long. 
